\title{
Influence of Seed Hardening and Foliar Spraying of PGRs on Morpho-physiological Parameters in Green Gram (Vigna radiata L.)
}

\author{
R.S. Bhadane ${ }^{1}$, K.R. Prajapati ${ }^{2}$, S.D. Rajput ${ }^{1}$, Kalyanrao Patil ${ }^{3}$
}

10.18805/IJARe.A-5865

\begin{abstract}
Background: Pre-sowing seed hardening and foliar spray with plant growth regulators is an easy, low cost and low risk technique and also an alternative approach recently used to mitigate the effect of abiotic stresses in agricultural production.

Methods: The mung bean var. GAM- 5 was treated with seed hardening treatments and also for foliar spray using $\mathrm{CaCl}_{2} 2 \%$ and $1 \%$, CCC $500 \mathrm{mg} / \mathrm{L}$, CCC $1000 \mathrm{mg} / \mathrm{L}$, NAA $25 \mathrm{mg} / \mathrm{L}$, NAA $50 \mathrm{mg} / \mathrm{L}$. during summer season of 2015-16 and 2016-17. The trial was laid out in RBD with three replications and sixteen treatment combinations.

Result: The results indicated a significant improvement in morpho-physiological growth parameters, dry matter production and thereby yield potential increased due to the application of plant growth regulators and agrochemical under field conditions. Among the different treatments, seed hardening with $2 \% \mathrm{CaCl}_{2}+1 \%$ foliar spraying at $30 \mathrm{DAS}\left(\mathrm{T}_{11}\right)$ treatment significantly improved most of morphophysiological parameters and thereby yield in green gram followed by the seed hardening treatments of Cycocel $1000 \mathrm{mg} / \mathrm{L}+$ foliar spraying at 30 DAS $\left(T_{13}\right)$ and seed hardening with NAA $50 \mathrm{mg} / \mathrm{L}+$ foliar spraying at 30 DAS $\left(T_{15}\right)$.
\end{abstract}

Key words: $\mathrm{CaCl}_{2}$, Cycocel, Dry matter partitioning, Foliar spray, Mung bean, NAA, Seed hardening.

\section{INTRODUCTION}

Mung bean (Vigna radiata L.) belongs to the family Leguminosae (Fabaceae) and had originated from India and Central Asia. Mung bean is one of the important pulse crops and rank third in area and production after pigeonpea and chickpea. India is the largest producer of mung bean accounting for almost 65 per cent of area and 54 per cent of production of the world. In addition to being an important source of human food and animal feed, pulses play an important role in maintaining the soil fertility in sustainable manner. It is a drought resistant crop and suitable for dry land farming and predominantly used as an intercrop with other crops. It is a very good catch crop in summer and can be grown very well in this season. Mung bean is a short duration, low input requiring crop that matures in 65 to 80 days, photo and thermo-insensitive in nature. The productivity of mung bean is low $(474 \mathrm{~kg} / \mathrm{ha})$.

Efforts made to maximize yield, are largely hampered by adverse effect of abiotic stress such as salinity and drought. These effects cause a huge loss due to low yield and failure of the crop to establish in harsh conditions. Presowing seed hardening treatment is an easy, low cost and low risk technique and also an alternative approach recently used to overcome the effect of abiotic stresses in agricultural production. It is found to be efficient in improving seed emergence and growth of crops. It was reported clearly that the hardening treatment enhance seeds vigour by protecting structure of the plasma membrane against injury during stress (Bewley and Black, 1982). It is a well established fact that, pre-soaking seeds with optimal concentration of phytohormones enhance their germination, dry matter accumulation and yield of some crop species under condition of environmental stress by increasing nutrient reserves
'Oilseeds Research Station, Mahatma Phule Agricultural University, Jalgaon-425 001, Maharashtra, India.

${ }^{2}$ Vanbandhu Krishi Polytechnic School, S.K. Nagar Agriculture University, Amirgadh-385 001, Gujarat, India.

${ }^{3}$ Department of Seed Science and Technology, Anand Agriculture University, Anand-388 110,Gujarat, India.

Corresponding Author: R.S. Bhadane, Oilseeds Research Station, Mahatma Phule Agricultural University, Jalgaon-425 001, Maharashtra, India. Email: bhadaners@rediffmail.com

How to cite this article: Bhadane, R.S., Prajapati, K.R., Rajput, S.D. and Patil, K. (2021). Influence of Seed Hardening and Foliar Spraying of PGRs on Morpho-physiological Parameters in Green Gram (Vigna radiata L.). Indian Journal of Agricultural Research. DOI: $10.18805 /$ IJARe.A-5865.

Submitted: 26-06-2021 Accepted: 30-09-2021 Online: 09-11-2021

through increased physiological activities and root proliferation.

Considering the constraints in the production potential of mung bean it is worthwhile to study the influence of different seed hardening and foliar spraying treatments on the production potential of mung bean. It is also of utmost importance to understand the physiological basis of plant height, number of branches, leaf area and dry matter accumulation and thereby yield variation due to seed hardening and foliar spraying of various growth regulators and chemicals. The manner in which the net dry matter is produced and distributed among the different parts of plant will determine the economic yield (Patil et al., 2007). The present study was therefore, undertaken to assess the pattern of plant height, leaf area and dry matter production in relation to yield in green gram. 


\section{MATERIALS AND METHODS}

The present work was carried out at Agronomy farm, Anand Agricultural University, Anand to study the influence of seed hardening and foliar spraying on morpho-physiological characters in green gram (Vigna radiata L.) during summer season of 2015-16 and 2016-17. The trial was laid out in RBD with three replications and sixteen treatment combinations including five seed hardening treatments, five foliar spraying treatments, five seed hardening treatments with foliar spraying and one absolute control treatment. Seeds of mung bean var. GAM- 5 were imposed with the following seed treatments.

The different solutions with different concentrations viz., $\mathrm{CaCl}_{2} 2 \%$, Cycocel $500 \mathrm{mg} \mathrm{l}^{-1}$ and $1000 \mathrm{mg} \mathrm{l}^{-1}$ and NAA 25 $\mathrm{mg} \mathrm{l}^{-1}$ and $50 \mathrm{mg} \mathrm{l}^{-1}$ were used in this experiment for seed hardening. The solutions were prepared by dissolving $10 \mathrm{~g}$ of $\mathrm{CaCl}_{2}$ directly in the water while $250 \mathrm{mg}$ and $500 \mathrm{mg}$ of Cycocel and $12.50 \mathrm{mg}$ and $25.00 \mathrm{mg}$ of NAA in small amount of ethyl alcohol separately and after dissolved completely, made the final volume up to $500 \mathrm{ml}$ by addition of water.

Seed hardening treatments were given to sufficient quantity of seeds of mung bean cv. GAM-5. For hardening, seeds were soaked in above prepared various solutions of double the volume of seed for three hours. The seeds were then removed from respective solutions and kept overnight in shade for drying to attained the seeds to its original moisture level. The seeds were ready for sowing in field on next day.

The different solutions with their different concentrations were used in this experiment for foliar spraying. Solutions of $\mathrm{CaCl}_{2} 1 \%$, Cycocel $500 \mathrm{mg} \mathrm{t}^{-1}$ and $1000 \mathrm{mg} \mathrm{t}^{-1}$ and NAA $25 \mathrm{mg} \mathrm{t}^{-1}$ and $50 \mathrm{mg} \mathrm{l}^{-1}$ were prepared by dissolving $100 \mathrm{~g}$ of $\mathrm{CaCl}_{2}$ directly in the water while $5.0 \mathrm{~g}$ and $10.0 \mathrm{~g}$ of Cycocel and $250 \mathrm{mg}$ and $500 \mathrm{mg}$ NAA in small amount of ethyl alcohol separately and made final quantity of 10 litter of each solution by water. The spraying was carried out as per treatments during the morning time or before noon at 30 days after sowing (DAS) in respective gross plot of each replication using knapsack sprayer.

\begin{tabular}{|c|c|}
\hline Treat. no. & Treatment details \\
\hline $\mathrm{T}_{1}$ & $\mathrm{CaCl}_{2} 2 \%$ Seed hardening $(\mathrm{SH})$ \\
\hline $\mathrm{T}_{2}$ & CCC $500 \mathrm{mg} / \mathrm{L}$ Seed hardening $(\mathrm{SH})$ \\
\hline $\mathrm{T}_{3}$ & CCC $1000 \mathrm{mg} / \mathrm{L}$ Seed hardening $(\mathrm{SH})$ \\
\hline $\mathrm{T}_{4}$ & NAA $25 \mathrm{mg} / \mathrm{L}$ Seed hardening $(\mathrm{SH})$ \\
\hline $\mathrm{T}_{5}$ & NAA $50 \mathrm{mg} / \mathrm{L}$ Seed hardening $(\mathrm{SH})$ \\
\hline $\mathrm{T}_{6}^{0}$ & $\mathrm{CaCl}_{2} 1 \%$ spraying at 30 days after sowing (DAS) \\
\hline $\mathrm{T}_{7}$ & CCC $500 \mathrm{mg} / \mathrm{L}$ spraying at 30 days after sowing (DAS) \\
\hline $\mathrm{T}_{8}$ & CCC $1000 \mathrm{mg} / \mathrm{L}$ spraying at 30 days after sowing (DAS) \\
\hline $\mathrm{T}_{9}$ & NAA $25 \mathrm{mg} / \mathrm{L}$ spraying at 30 days after sowing (DAS) \\
\hline$T_{10}$ & NAA $50 \mathrm{mg} / \mathrm{L}$ spraying at 30 days after sowing (DAS) \\
\hline $\mathrm{T}_{11}$ & $\begin{array}{l}\mathrm{CaCl}_{2} 2 \% \text { Seed hardening }(\mathrm{SH})+1 \% \text { spraying at } \\
30 \text { days after sowing (DAS) }\end{array}$ \\
\hline $\mathrm{T}_{12}$ & $\begin{array}{l}\text { CCC } 500 \mathrm{mg} / \mathrm{L} \text { Seed hardening }(\mathrm{SH})+\text { spraying at } \\
30 \text { days after sowing (DAS) }\end{array}$ \\
\hline$T_{13}$ & $\begin{array}{l}\text { CCC } 1000 \mathrm{mg} / \mathrm{L} \text { Seed hardening }(\mathrm{SH})+\text { spraying at } \\
30 \text { days after sowing (DAS) }\end{array}$ \\
\hline $\mathrm{T}_{14}$ & $\begin{array}{l}\text { NAA } 25 \mathrm{mg} / \mathrm{L} \text { Seed hardening }(\mathrm{SH})+\text { spraying at } \\
30 \text { days after sowing (DAS) }\end{array}$ \\
\hline $\mathrm{T}_{15}$ & $\begin{array}{l}\text { NAA } 50 \mathrm{mg} / \mathrm{L} \text { Seed hardening }(\mathrm{SH})+\text { spraying at } \\
30 \text { days after sowing (DAS) }\end{array}$ \\
\hline $\mathrm{T}_{16}$ & Absolute control \\
\hline
\end{tabular}

\section{Morphological growth parameters}

Five plants from each plot were tagged randomly at seedling stage for recording various morphological observations at $30,45,60$ DAS and at harvest. Plant height and number of branches per plant were recorded by non destructive method from each replication and treatment and the average values were calculated.

\section{Leaf area $\left(\mathrm{cm}^{2}\right.$ plant $\left.^{-1}\right)$}

Leaf area per plant was taken at harvest with the help of Leaf area meter (Model- 3100) at regional research station. Five plants were randomly selected from all replications and clipped and recorded.

\section{Total dry matter production}

Sampling was done at every 15 days interval from 30 DAS until harvest regardless of growth stage. The total dry matter production was recorded by destructive method. Randomly selected five plant samples were uprooted and separated into root, leaf, stem and reproductive parts and dried in oven at $80^{\circ} \mathrm{C}$ until constant weight was obtained. Total dry matter was calculated by adding dry weight of different plant parts and expressed as grams per plant at different intervals 30 , 45,60 and at harvest of crop growth period.

\section{RESULTS and DISCUSSION \\ Plant height $(\mathrm{cm})$ at 30, 45, 60 DAS and at harvest}

The data on plant height at various growth stages were analyzed statistically are represented in Table 1 . Among the treatments seed hardening with $2 \% \mathrm{CaCl}_{2}\left(\mathrm{~T}_{11}\right.$ and $\left.\mathrm{T}_{1}\right)$ recorded significantly higher plant height $(11.33 \mathrm{~cm}$ and $11.00 \mathrm{~cm}$ ) respectively at 30 DAS in summer 2016 . During 2017 as well as in pooled basis $2 \% \mathrm{CaCl}_{2}\left(\mathrm{~T}_{11}\right.$ and $\left.\mathrm{T}_{1}\right)$ recorded significantly higher plant height $(12.50,11.92 \mathrm{~cm}$ and $12.00,11.50 \mathrm{~cm}$ ) respectively at 30 DAS. These results are in accordance with the research findings of Manjunath and Dhanoji (2011). The lowest plant height was recorded $(8.00,8.83$ and $8.42 \mathrm{~cm})$ during 2016, 2017 and in pooled analysis respectively with untreated absolute control $\left(T_{16}\right)$ as well as $T_{9}$ and $T_{10}$. However, the treatment seed hardening with $2 \% \mathrm{CaCl}_{2}\left(\mathrm{~T}_{11}\right.$ and $\left.\mathrm{T}_{1}\right)$ remained at par with other treatments viz., $\mathrm{T}_{2}, \mathrm{~T}_{3}, \mathrm{~T}_{5}, \mathrm{~T}_{12}, \mathrm{~T}_{13}, \mathrm{~T}_{14}$ and $\mathrm{T}_{15}$ at $30 \mathrm{DAS}$.

At 45 DAS the plant height was significantly superior in the treatment $\mathrm{CaCl}_{2} 2 \%$ seed hardening $+1 \%$ spraying at 30 DAS $\left(T_{11}\right)(26.00,28.33$ and $27.17 \mathrm{~cm})$. It was followed by the treatments with NAA $50 \mathrm{mg} / \mathrm{L}$ seed hardening + spraying at $30 \mathrm{DAS}\left(\mathrm{T}_{15}\right)(25.67,28.00$ and $26.83 \mathrm{~cm})$ and NAA $25 \mathrm{mg} / \mathrm{L}$ seed hardening + spraying at 30 DAS $\left(T_{14}\right)$ $(25.00,27.33$ and $26.17 \mathrm{~cm})$. The treatment CCC $1000 \mathrm{mg} /$ $\mathrm{L}$ spraying at $30 \mathrm{DAS}\left(\mathrm{T}_{8}\right)$ recorded significantly lower plant height $(18.33,19.00$ and $18.67 \mathrm{~cm})$ during 2016, 2017 and in pooled basis, respectively. The treatments showed same trend at 60 DAS and at harvest stage for plant height.

Plant height was increased due to treatments of $\mathrm{CaCl}_{2}$ and NAA, while decreased due to Cycocel at various growth stages viz., 45 DAS, 60 DAS and at harvest in green gram. 


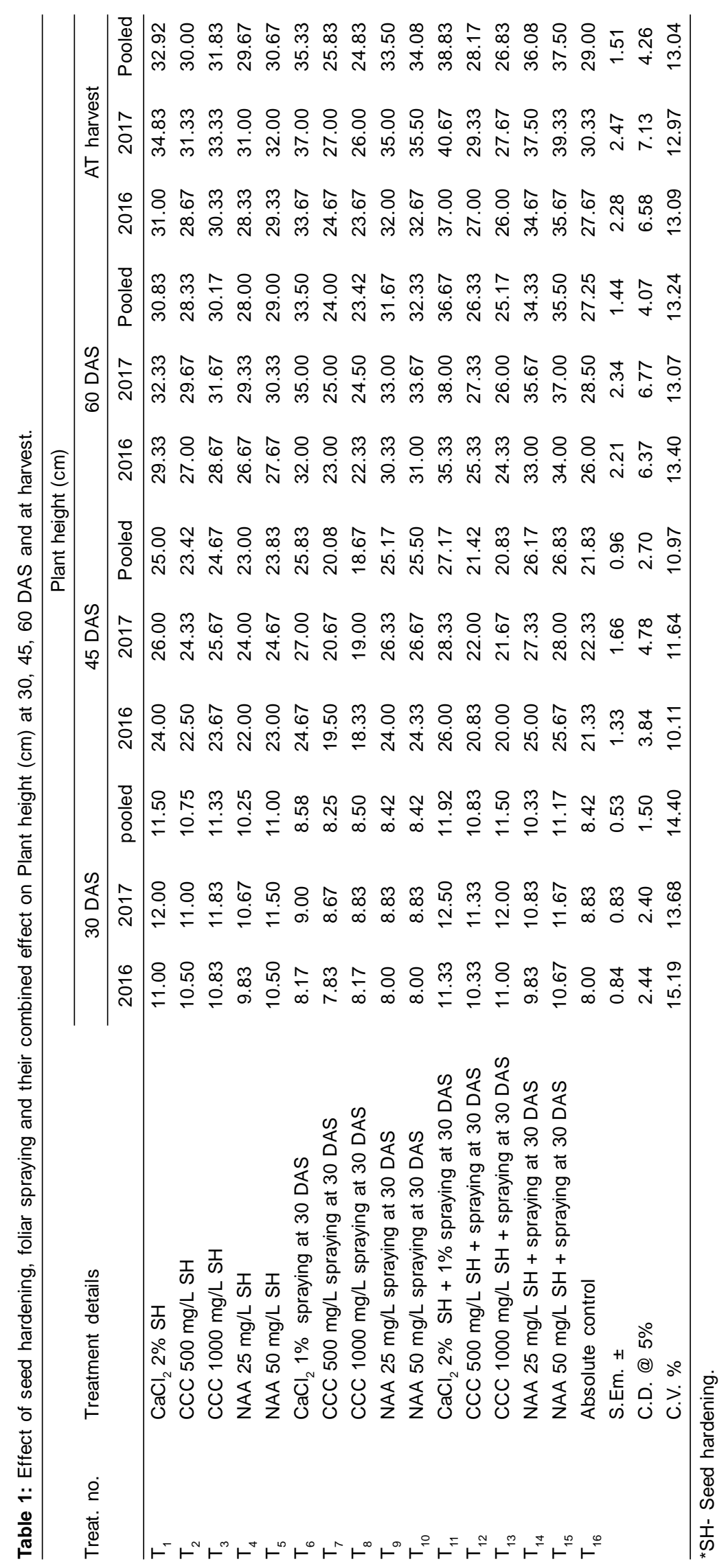


The decrease in plant height with cycocel may be attributed to anti - auxin activity of Cycocel. It blocked the synthesis of IAA in the plant system. The mechanism of reduction of plant height by spraying with Cycocel also appears due to reduced cell size and cell wall thickening or reduction in the cell division activity (Ginzo et al., 1977). Similar results observed by Sujatha (2014) in chickpea and Kinjal (2017) in black gram.

It was observed that NAA showed a positive effect among the different treatments. The application of auxin in plant has a role in the stimulation of RNA and protein synthesis and greater enhancement in photosynthesis rate, increased in cell elongation as well as cell division and cell wall plasticity, which ultimately showed the enhancement in various growth parameters. The above finding were in agreement with the results reported by Ananthi and Mallika (2014) in green gram, Sunil Jadhav (2016) and Kinjal (2017) in black gram, Pothalkar (2007) in pigeon pea, Sujatha et al (2017) in chickpea.

\section{Number of branches per plant at $30,45,60$ DAS and at harvest}

The results on number of branches per plant were analyzed statistically and represented in Table 2. Among the treatments, seed hardening with CCC $1000 \mathrm{mg} / \mathrm{L}\left(\mathrm{T}_{13}\right.$ and $\mathrm{T}_{3}$ ) recorded significantly higher number of branches per plant (3.70) and absolute control $\left(\mathrm{T}_{16}\right)$ and $\mathrm{T}_{7}$ recorded lowest (3.23) at 30 DAS. However, the treatments $T_{11}$ and $T_{1}, T_{12}$ and $T_{2}$ as well as $T_{15}$ and $T_{5}$ remained at par with the treatments $T_{13}$ and $T_{3}$ at 30 DAS in pooled analysis. On pooled basis, CCC $1000 \mathrm{mg} / \mathrm{L}$ seed hardening + spraying at 30 DAS $\left(T_{13}\right)$ recorded significantly maximum $(6.28,8.13$ and 8.67) number of branches per plant than untreated absolute control $(4.94,6.27$ and 6.67$)$ at 45 DAS, 60 DAS and at harvest, respectively.

The reduction in plant height due to growth retardants is mainly seem to have released the apical dominance and diversion of the plant metabolites from vertical growth to horizontal growth and thereby more number of branches per plant. As the apical dominance is removed usually the plant itself adjusts to encourage the growth of auxiliary buds which then converted into branches. Similar results were obtained in pigeon pea by Arjun Sharma et al. (2003) and Manjunath and Dhanoji (2011) and Sujatha (2014) in chickpea.

\section{Leaf area at 30 DAS, 45 DAS, 60 DAS and at harvest $\left(\mathrm{cm}^{2}\right.$ plant $\left.^{-1}\right)$}

The data regarding leaf area per plant were recorded and analyzed statistically are furnished in Table 3. The data revealed that pre-sowing seed hardening with $2 \% \mathrm{CaCl}_{2}\left(\mathrm{~T}_{11}\right.$ and $\left.T_{1}\right)$ recorded significantly higher leaf area per plant (194, 222, $208 \mathrm{~cm}^{2}$ and 191, 220, $206 \mathrm{~cm}^{2}$ ) while lower total leaf area per plant was observed $\left(102,114\right.$ and $\left.108 \mathrm{~cm}^{2}\right)$ in untreated absolute control $\left(T_{16}\right)$ at 30 DAS during summer 2016 and 2017 seasons as well as in pooled analysis, respectively. The treatments viz., CCC $1000 \mathrm{mg} / \mathrm{L}\left(\mathrm{T}_{13}\right.$ and $\left.\mathrm{T}_{3}\right)(180,210$ $\mathrm{cm}^{2}$ and $\left.177,209 \mathrm{~cm}^{2}\right)$ remained at par with the treatments $2 \% \mathrm{CaCl}_{2}\left(\mathrm{~T}_{11}\right.$ and $\left.\mathrm{T}_{1}\right)$ at $30 \mathrm{DAS}$ during 2016 and 2017 seasons, respectively. The treatment $\mathrm{CaCl}_{2} 2 \%$ seed hardening $+1 \%$ spraying at 30 DAS $\left(T_{11}\right)$ recorded significantly highest total leaf area per plant $(422,607$ and $\left.395 \mathrm{~cm}^{2}\right)$ and remained at par with the treatments $T_{13}(411$, 594 and $\left.387 \mathrm{~cm}^{2}\right), \mathrm{T}_{15}\left(399,583\right.$ and $\left.374 \mathrm{~cm}^{2}\right)$ and $T_{12}$ (397, 576 and $368 \mathrm{~cm}^{2}$ ) at 45 DAS, 60 DAS and at harvest, respectively. The untreated absolute control $\left(T_{16}\right)$ recorded significantly the lowest $\left(270,419\right.$ and $\left.244 \mathrm{~cm}^{2}\right)$ leaf area per plant.

The increased in leaf area by seed hardening and foliar spraying with $\mathrm{CaCl}_{2}$, Cycocel and NAA might be due to increase in cell division, cell enlargement as well as induce more extensive and denser network of veins and ribs and there by increased foliar leaf area. These results are conformity with the finding of Ginzo et al. (1977) in chick pea, Shinde and Jadhav (1995) in cowpea, Prabhu (2000) in blackgram, Pothalkar (2007) in pigeonpea, Prakash et al. (2013) in rice and Kinjal (2017) in black gram. Kalubarme and Pandey (1979) also reported that leaf area increased with an increase in time to a maximum coinciding with maximum top growth and steady decline at later stage.

\section{Dynamics of dry matter accumulation}

Both treatments and sampling time i.e. growth stage had a significant effect on dry matter accumulation ( $\left.\mathrm{g} \mathrm{plant}^{-1}\right)$. Production of dry matter was slow during the first month after sowing, which is typical for legumes adapted to winter conditions (Zapata et al., 2019). In early growth phase larger portion of total dry matter was shared by the leaves than the stem. The dry matter accumulation in pods initiated after 30 DAS with reproductive parts like flowers and continued to increase upto the harvest.

In the present study, significant differences were observed in the total dry matter per plant. The data regarding total dry matter accumulation per plant were analyzed statistically and furnished in Table 4.

\section{Total dry matter production at various growth stages}

The total dry matter production per plant is aggregate of stem, leaf, root and reproductive dry matter accumulation at respective growth stages. It was increased progressively and differed significantly at all the growth stages from sowing to harvest in green gram. The results pertaining to the total dry matter (TDM) production indicated significant differences and revealed that pre-sowing seed hardening with $2 \% \mathrm{CaCl}_{2}$ $\left(T_{11}\right.$ and $\left.T_{1}\right)$ recorded highest total dry weight per plant (4.393, $5.043,4.718$ and $4.383,5.000,4.692 \mathrm{~g})$ while lowest total dry matter production was recorded $(3.450,4.033$ and $3.742 \mathrm{~g})$ in untreated absolute control $\left(\mathrm{T}_{16}\right)$ at 30 DAS during summer 2016, 2017 seasons and in pooled analysis, respectively. The treatment with $\mathrm{CaCl}_{2} 2 \%$ seed hardening $+1 \%$ spraying at 30 DAS $\left(T_{11}\right)$ recorded highest total dry matter accumulation per plant $(13.013,14.537$ and $13.775 \mathrm{~g})$ at 45 DAS, at 60 DAS $(27.057,30.417$ and $28.737 \mathrm{~g})$ and at harvest $(29.720,33.420$ and $31.570 \mathrm{~g})$ during summer 2016 , 


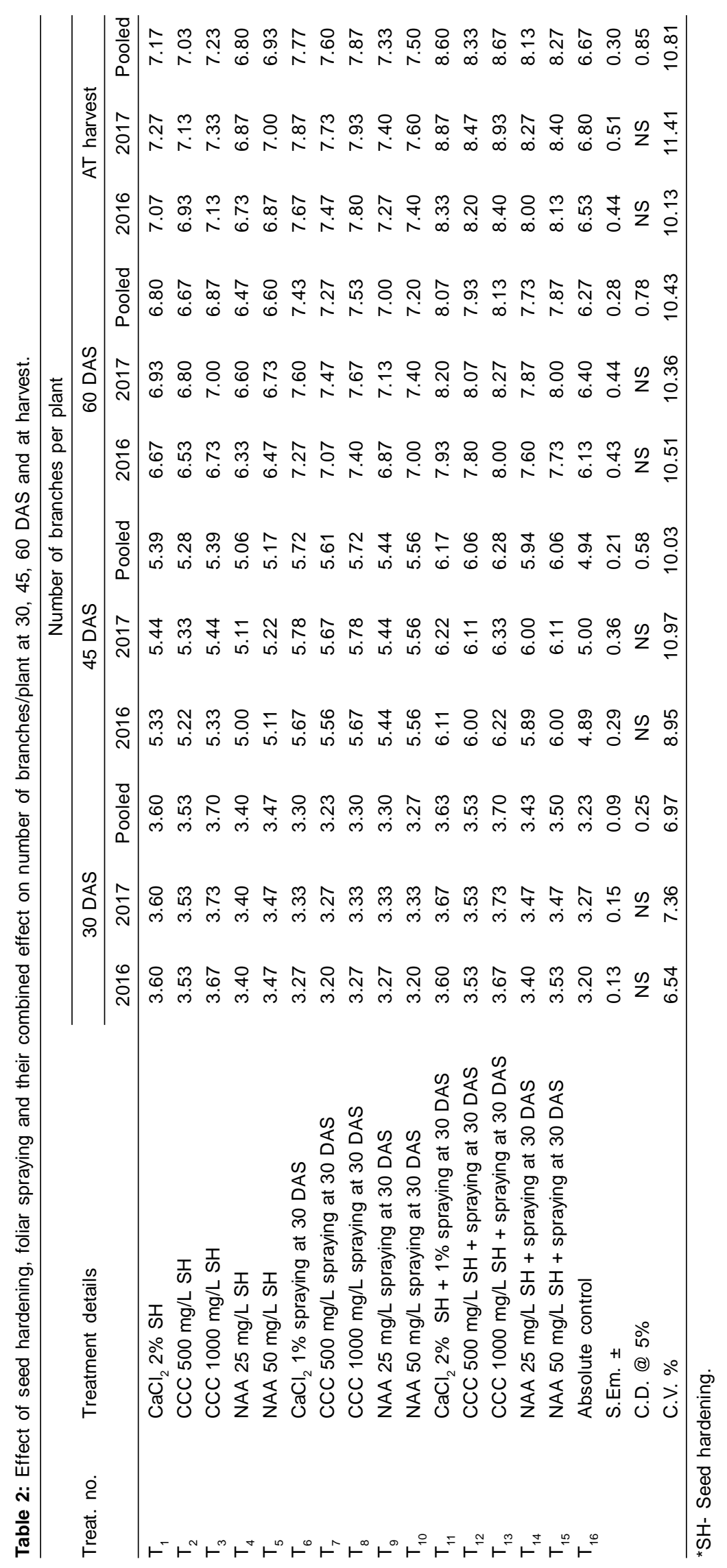




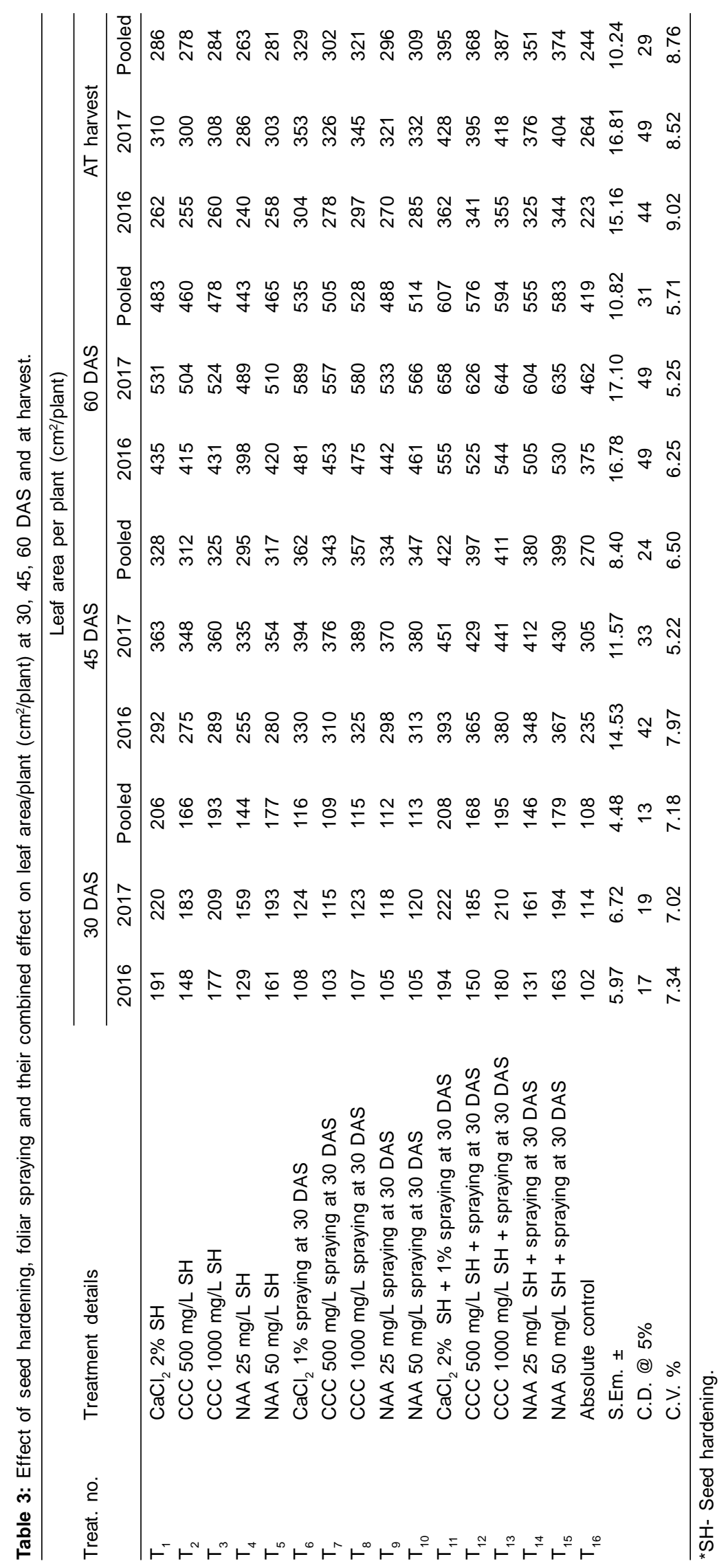




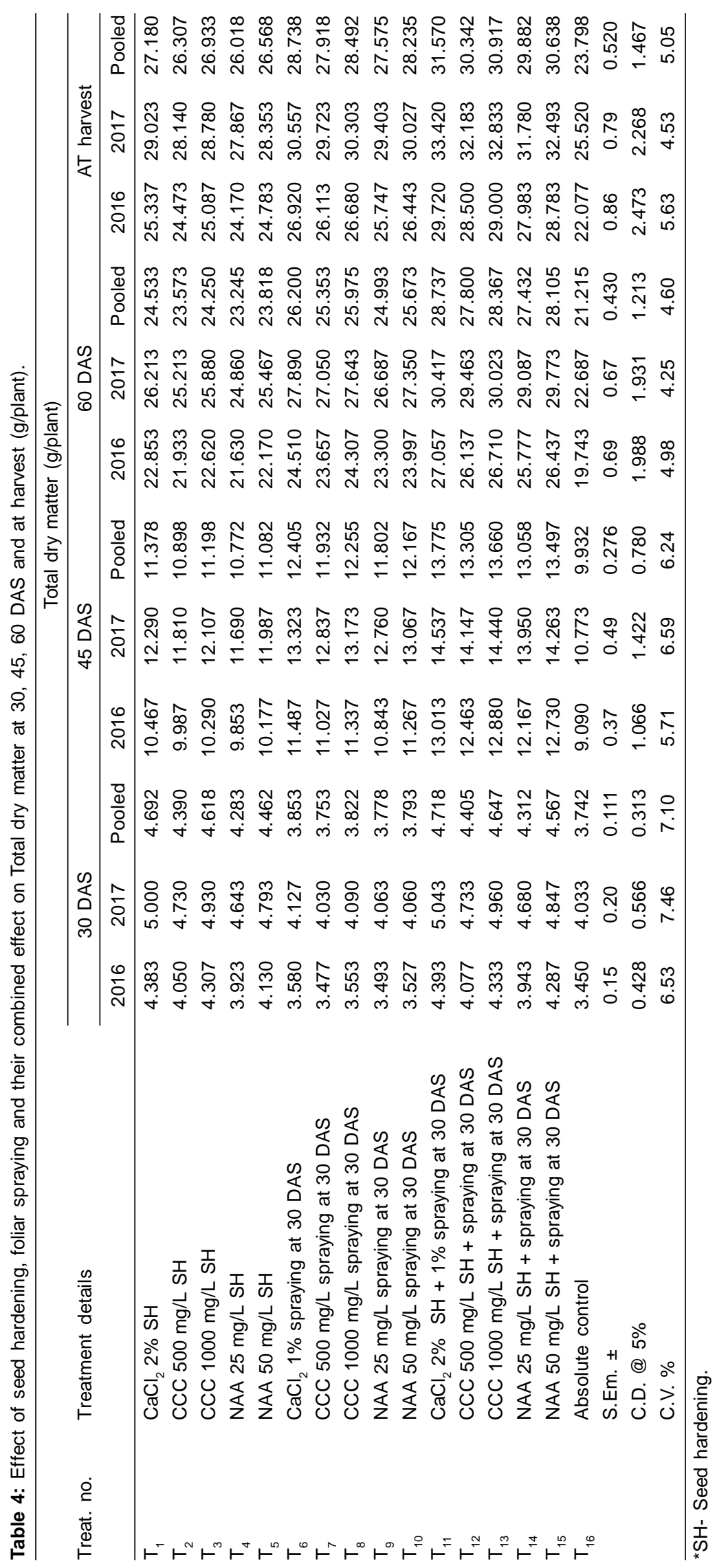


2017 seasons and in pooled analysis, respectively (Table 4). The increase in TDM production towards maturity may be due to indeterminate growth pattern, higher rate of $\mathrm{CO}_{2}$ fixation and RuBP carboxylase activity during crop growth. The association of TDM partitioning with grain yield was more significant at all the stages of crop growth. Thus, TDM production and partitioning is an important parameter in boosting the source-sink relationship and ultimately yield potential. Similar observations were also made by Nam et al. (1998), Katti et al. (1999), Manjunatha (2007), Sujatha (2014) in chickpea and Patil et al., (2007) in groundnut. Thus, the total dry matter is composed of more with the leaf and stem dry weight and little with root dry weight during vegetative growth phase. But during reproductive growth phase, reproductive parts like pods, flowers contributes more as compared to leaf, stem and root dry weight. Murthy et al. (2002) corroborated the increase in dry matter in any genotype might reflect in increase in yield contributing characters and ultimately final economic yield and positive correlation of dry pod yield with dry matter accumulation.

\section{Seed yield per plant $\left(\right.$ g plant $\left.^{-1}\right)$}

The data regarding seed yield per plant and seed yield per hectare were recorded and analyzed statistically are furnished in Table 5. The treatment $\mathrm{CaCl}_{2} 2 \%$ seed hardening $+1 \%$ spraying at $30 \mathrm{DAS}\left(\mathrm{T}_{11}\right)$ recorded significantly higher values of seed yield per plant $(13.07,14.20$ and $13.63 \mathrm{~g})$ and remained at par with $\mathrm{T}_{13}(12.60,13.93$ and $13.27 \mathrm{~g}), \mathrm{T}_{15}$ $(12.47,13.60$ and $13.03 \mathrm{~g})$ and $T_{12}(12.13,13.27$ and 12.70 g) during 2016, 2017 and on pooled basis, respectively. Whereas, the treatment of absolute control $\left(T_{16}\right)$ recorded significantly lowest yield per plant $(8.07,9.40$ and $8.73 \mathrm{~g}$, respectively).

\section{Seed yield per hectare $\left(\mathrm{kg} \mathrm{ha}^{-1}\right)$}

The significantly highest seed yield per hectare (949, 1006 and $978 \mathrm{~kg} \mathrm{ha}^{-1}$ ) was recorded by the treatment $T_{11}$ which remained at par with the treatments $T_{13}(922,964$ and 943 $\left.\mathrm{kg} \mathrm{ha}^{-1}\right)$ and $\mathrm{T}_{15}\left(893,917\right.$ and $\left.905 \mathrm{~kg} \mathrm{ha}^{-1}\right)$. While significantly the lowest seed yield per hectare was observed in the absolute control (639, 679 and $659 \mathrm{~kg} \mathrm{ha}^{-1}$ ) during 2016, 2017 and in pooled analysis, respectively (Table 5).

Improvement in yield could happen in two ways i.e., by adopting the existing varieties to grow better in their environment or by altering the relative proportion of different plant parts so as to increase the yield of economically important parts. The influence of plant growth regulators and seed hardening chemicals significantly increased the seed yield. The present study also revealed that increase in seed yield was significantly higher in seed hardening + spraying with $\mathrm{CaCl}_{2}$ (2\% seed hardening and $1 \%$ spraying) followed by Cycocel $1000 \mathrm{mg} / \mathrm{L}$ and NAA $50 \mathrm{mg} / \mathrm{L}$. This could probably be due to beneficial effects of agrochemical and plant growth regulator treatments which help in enhancement of photosynthesis and nitrogen metabolism which are the major physiological process influencing plant growth and development. The treatments of $\mathrm{CaCl}_{2}$ was significantly superior as compared to other treatments in enhancing the plant height, number of branches per plant, leaf area, dry matter production and thereby seed yield. The increase in the higher yield may be due to better carbon assimilation, better accumulation of carbohydrates and reduced

Table 5: Seed yield as influenced by seed hardening, foliar spraying and their combined effect at harvest.

\begin{tabular}{|c|c|c|c|c|c|c|c|}
\hline \multirow{2}{*}{ Treat. no. } & \multirow{2}{*}{ Treatment details } & \multicolumn{3}{|c|}{ Seed yield/plant (g plant ${ }^{-1}$ ) } & \multicolumn{3}{|c|}{ Seed yield/ha (kg ha $\left.{ }^{-1}\right)$} \\
\hline & & 2016 & 2017 & Pooled & 2016 & 2017 & Pooled \\
\hline $\mathrm{T}_{1}$ & $\mathrm{CaCl}_{2} 2 \% \mathrm{SH}$ & 10.00 & 11.20 & 10.60 & 741 & 769 & 755 \\
\hline $\mathrm{T}_{2}$ & CCC 500 mg/L SH & 9.47 & 10.60 & 10.03 & 697 & 737 & 717 \\
\hline $\mathrm{T}_{3}$ & CCC $1000 \mathrm{mg} / \mathrm{L} \mathrm{SH}$ & 9.87 & 11.00 & 10.43 & 721 & 761 & 741 \\
\hline $\mathrm{T}_{4}$ & NAA 25 mg/L SH & 9.00 & 10.33 & 9.67 & 674 & 701 & 688 \\
\hline $\mathrm{T}_{5}$ & NAA $50 \mathrm{mg} / \mathrm{L} \mathrm{SH}$ & 9.60 & 10.87 & 10.23 & 702 & 752 & 727 \\
\hline $\mathrm{T}_{6}$ & $\mathrm{CaCl}_{2} 1 \%$ spraying at 30 DAS & 11.00 & 12.20 & 11.60 & 799 & 845 & 822 \\
\hline $\mathrm{T}_{7}$ & CCC $500 \mathrm{mg} / \mathrm{L}$ spraying at 30 DAS & 10.47 & 11.60 & 11.03 & 764 & 800 & 782 \\
\hline $\mathrm{T}_{8}$ & CCC $1000 \mathrm{mg} / \mathrm{L}$ spraying at 30 DAS & 10.80 & 12.07 & 11.43 & 779 & 831 & 805 \\
\hline $\mathrm{T}_{9}$ & NAA $25 \mathrm{mg} / \mathrm{L}$ spraying at 30 DAS & 10.13 & 11.33 & 10.73 & 745 & 785 & 765 \\
\hline $\mathrm{T}_{10}$ & NAA $50 \mathrm{mg} / \mathrm{L}$ spraying at 30 DAS & 10.53 & 11.80 & 11.17 & 765 & 825 & 795 \\
\hline $\mathrm{T}_{11}$ & $\mathrm{CaCl}_{2} 2 \% \mathrm{SH}+1 \%$ spraying at $30 \mathrm{DAS}$ & 13.07 & 14.20 & 13.63 & 949 & 1006 & 978 \\
\hline $\mathrm{T}_{12}$ & CCC $500 \mathrm{mg} / \mathrm{L} \mathrm{SH}+$ spraying at $30 \mathrm{DAS}$ & 12.13 & 13.27 & 12.70 & 860 & 880 & 870 \\
\hline $\mathrm{T}_{13}$ & CCC $1000 \mathrm{mg} / \mathrm{L} \mathrm{SH}+$ spraying at $30 \mathrm{DAS}$ & 12.60 & 13.93 & 13.27 & 922 & 964 & 943 \\
\hline $\mathrm{T}_{14}$ & NAA $25 \mathrm{mg} / \mathrm{L} \mathrm{SH}+$ spraying at $30 \mathrm{DAS}$ & 11.80 & 12.93 & 12.37 & 835 & 866 & 851 \\
\hline $\mathrm{T}_{15}$ & NAA $50 \mathrm{mg} / \mathrm{L} \mathrm{SH}+$ spraying at $30 \mathrm{DAS}$ & 12.47 & 13.60 & 13.03 & 893 & 917 & 905 \\
\hline \multirow[t]{4}{*}{$\mathrm{T}_{16}$} & Absolute control & 8.07 & 9.40 & 8.73 & 639 & 679 & 659 \\
\hline & S.Em. \pm & 0.59 & 0.56 & 0.36 & 55.36 & 55.94 & 35.29 \\
\hline & C.D. @ 5\% & 1.70 & 1.61 & 1.02 & 160 & 162 & 100 \\
\hline & C.V. \% & 9.51 & 8.10 & 8.77 & 12.29 & 11.82 & 12.05 \\
\hline
\end{tabular}

\footnotetext{
${ }^{*} \mathrm{SH}$ - Seed hardening.
} 
respiration in plants. These results are in agreement with the findings of Mahabir singh and Rajodia (1989) in soybean and Pothalkar (2007) in pigeon pea.

\section{CONCLUSION}

Based on the above results, it is concluded that the yield potential in green gram can be improved by using plant growth regulators and agrochemical. The results also indicated a significant improvement in morpho-physiological growth parameters, dry matter production and thereby yield due to the application of PGR's and agrochemical. Among the different treatments, seed hardening with $2 \% \mathrm{CaCl}_{2}+$ $1 \%$ foliar spraying at 30 DAS treatment significantly improved the most of morpho-physiological parameters and thereby yield in green gram followed by the seed hardening treatments of Cycocel $1000 \mathrm{mg} / \mathrm{L}+$ foliar spraying at 30 DAS and seed hardening with NAA $50 \mathrm{mg} / \mathrm{L}+$ foliar spraying at 30 DAS.

\section{REFERENCES}

Ananthi, K. and Mallika, V. (2014). Foliar spray of humic acid with growth regulators in nutrient content and yield of greengram [Vigna radiata (L.) Wilczek]. Legume Research. 37(4): 359-62.

Arjun, S., Potdar, M.P., Pujari, B.T., Dharmaraj, P.S. and Sharma, A. (2003). Studies on response of pigeon pea to canopy modification and plant geometry. Karnataka Journal of Agricultural Science. 16: 1-3.

Bewley, J.D. and Black, M. (1982). Physiology and Biochemistry of Seeds in Relation to Germination. Springer, Berlin, 2: p 375.

Ginzo, H.D., Carcellas, M.S. and Fonseca, E. (1977). CCC (2chloroethyl trimethyl ammonium chloride) and the regulation of plant water status in wheat (Triticum aestivum L.). Phyton Argentina. 35: 82-92.

Kalubarme, M.H. and Pandey, R.K. (1979). Note on the growth analysis of green gram genotypes. Indian Journal of Agricultural Sciences. 49: 975-77.

Katti, V.S., Sheelavantar, M.N., Malipatil, T.B. and Bellakki, M.A. (1999). Effect of intercropping of short, medium and long duration pigeonpea (Cajanus cajana L.) with groundnut (Arachis hypogaea L.) on dry matter production and its accumulation in different parts. Annals of Plant Physiology. 13(1): $1-4$.

Kinjal, R. Prajapati. (2017). Effect of seed hardening on germination, growth and yield of black gram (Vigna mungo L.). M. Sc. (Agri.) Thesis, Anand Agricultural University, Anand, Gujarat, India.

Mahabir, S. and Rajodia, R.B. (1989). Effect of gibberellic acid on growth and yield attributes of radish varieties. Indian Journal of Plant Physiology. pp. 167-71.
Manjunath, B.L. (2007). Physiological basis of seed hardening in chickpea (Cicer arietinum. L). M. Sc. (Agri.) Thesis, University of Agricultural Sciences, Dharwad, Karnataka, India.

Manjunath, B.L. and Dhanoji, M.M. (2011). Effect of seed hardening with chemicals on drought tolerance traits and yield in chickpea. (Cicer arietinum. L). Journal of Agricultural Sciences. 3(3): 186-89.

Murthy, S.K.K., Padmalatha, Y. and Rao, A.Y. (2002). Impact of drought on dry matter production and yield of groundnut (Arachis hypogaea L.) during kharif season. Agro Meteorology. 4(2): 195-197.

Nam, N.H., Subbarao, G.V., Chauhan, Y.S. and Johansen, C. (1998). Importance of canopy attributes in determining dry matter accumulation of pigeonpea under contrasting moisture regimes. Crop Science. 38: 955-61.

Patil, S.S., Bhadane, R.S., Patil, T.R. and Patil, A.J. (2007). Dry matter accumulation and its distribution in various plant parts in drought resistant groundnut genotypes. PKV Research Journal. 31(2): 192-196.

Prakash, M., Narayanan, G., Sunil, B. and Kamaraj, A. (2013). Effect of seed hardening and pelleting on seed quality and physiology of rice in aerobic condition. Agriculture Science Digest. 33(3): 172-77.

Pothalkar, S.M. (2007). Physiological investigations on drought tolerance in pigeonpea (Cajanus cajan L.). Ph. D. Thesis, University of Agricultural Sciences, Dharwad, Karnataka, India.

Prabhu, D. (2000). Influence of plant growth regulators and micronutrients in blackgram (Vigna mungo). M. Sc. (Agri.) Thesis, University of Agricultural Sciences, Dharwad, Karnataka, India.

Shinde, A.K. and Jadhav, B.B. (1995). Influence of NAA, ethrel and $\mathrm{KNO}_{3}$ on leaf physiology and yield of cowpea. Annals of Plant Physiology. 9: 43-46.

Sujatha, M. (2014). Studies on effect of seed hardening, nipping and foliar spray of cycocel on growth, yield and quality of chickpea (Cicer arietinum L.). M. Sc. (Agri.) Thesis, University of Agricultural Sciences, Dharwad, Karnataka, India.

Sujatha, M., Uppar, D.S., Deshpande, V.K. and Nawalagatti, C. M. (2017). Effect of seed hardening nipping and foliar spray of cycocel on growth, yield and quality of chickpea (Cicer arientinum L.). Environment and Ecology. 35(2): 703-07.

Sunil, J. (2016). Enfluence of plant growth regulators and micronutrients on growth and seed yield of black gram. M. Sc. (Agri.) Thesis, University of Agricultural Sciences, Bengaluru, Karnataka, India.

Zapata, Hernández, I., Rodríguez, Macías, R., García, López, P.M., Salcedo, Perez, E., Lara, Rivera, A.H. and Zamora, Natera, J.F. (2019). Dry matter yield and nitrogen content in Lupinus spp. (Leguminosae) with potential as a green manure. Legume Research. 42(4): 523-527. 